\title{
THE ACTUAL LEVEL OF PENSION PROVISION IN RUSSIA
}

\author{
Oksana V. Skotarenko ${ }^{1}$ \\ Svetlana V. Bespalova ${ }^{2}$ \\ Larisa B. Seneckaya ${ }^{3}$
}

\begin{abstract}
The problem of the pension system modernization focused on improving Russian citizens' standard of living remains relevant in contemporary Russia. The study aims at developing proposals to improve the

improve the pension system. The core of the study is to substantiate the need to reform the pension system focused on improving the living standards for citizens of retirement age in the Russian Federation.
\end{abstract} living standards for citizens of retirement age in Russia in the context of pension system reforms. Systematic methodological approach and methods of statistical and economic analysis, including methods of horizontal and vertical analysis, enabled assessments of the dynamics and structure of revenue and expenditure of the Pension Fund, the number of working pensioners in the Russian Federation. The calculation of pension for individuals is carried out by ratio analysis. The comparative analysis enabled the assessment of differences in living standards of pensioners in the Far North and other regions of Russia. The study has determined the reasons for continued employment of pensioners in the Russian Federation; the pension scheme for individuals; perspective directions to

Keywords: pension system, pension reform, insurance and cumulative pension, individual pension coefficient, calculated and fixed pension, retirement age.

\section{Introduction}

Pension plays a significant role in the economic, social and political life of the state. In the current context, there are problems caused by:

- the tendency to reduce the number of employed in the economy of Russia;

- increased socio-demographic demands per worker;

- implementation of targeted state programs to increase life expectancy, social security, improve the health system;

\footnotetext{
${ }^{1}$ Murmansk Arctic State University

${ }^{2}$ Murmansk Arctic State University

${ }^{3}$ Murmansk Arctic State University
} 
the need for rational use of the Pension Fund of the Russian Federation.

The objective of the study is to develop proposals to improve the living standards for citizens of retirement age in Russia in the context of pension system reforms.

To achieve this objective, the following tasks have been implemented:

- the analysis of the dynamics and structure of revenue and expenditure of the Pension Fund, the number of working pensioners in Russia;

- a comparative analysis of living standard of pensioners in the Far North and other regions of Russia.

- the directions for the pension system improvement have been identified.

E. Baranova [7], D. Ermakov [9], I. Kruchek [10], A. Silchuk [15, 16, 17] should be noted among domestic authors, considering the peculiarities and problems of pension schemes in Russia. Foreign researchers F. Stewart [19] and M. Walsh [21] deal with pension provision. The problems of pension planning are reflected inthe writings of T. Everett, J. Melone, D. Rosenbloom [22], and J. VanDerhei [28]. Social security and pension issues were considered by G. Avy [23], G. Janice [25], O.Mitchell, R. Myers, and H. Young [24]. K. Geoffrey, R. Schmitt, and M. Harlan [26], M.
Dan, K. Brown, J. Haley, and S. Schieber [27] were engaged in identifying factors affecting the level of pension provision. The policy of social pension provision is reflected in the scientific developments of O. Kelly, J. VanDerhei, D. Salisbury [28], Sh. James and T. Leavitt [29], W. Wiatrowski [30].

\section{Materials and methods.}

Reliability of results is ensured by: - using the actual data (annual state statistical report, reports of the Pension Fund of the Russian Federation, the legislative and regulatory framework of the Russian Federation) in combination with the author's own research and calculations in relation to the pension system;

- scientific methodology and technique, based on domestic and foreign experience; application of proven methods of scientific research: sampling, grouping, comparison, generalization; graphical description is made using histograms and time series graphs.

The tasks have been solved in the form of such a sequence of stages:

at the first stage, a sample of statistical data of the annual state statistical report and reports of the Pension Fund of the Russian Federation over the last 3 years was selected; the second stage involves a horizontal and vertical analysis of revenue and expenditure of the Pension Fund, the implementation of 
the federal budget and the budget of the Pension Fund of the Russian Federation, the number of working pensioners; at the third stage, proposals for improving the pension system of the Russian Federation were developed.

\section{Results}

Table 1

Dynamics of revenue and expenditure of the Pension Fund of the Russian Federation in 2014 and 2016

\begin{tabular}{|l|c|c|c|c|c|c|}
\hline \multirow{5}{*}{ Indicator } & \multicolumn{2}{|c|}{2014} & \multicolumn{2}{c|}{2015} & \multicolumn{2}{c|}{2016} \\
\cline { 2 - 7 } & $\begin{array}{c}\text { Total } \\
\text { volume, } \\
\text { billion } \\
\text { rubles }\end{array}$ & $\begin{array}{c}\text { Share of } \\
\text { GDP, \% }\end{array}$ & $\begin{array}{c}\text { Total } \\
\text { volume, } \\
\text { billion } \\
\text { rubles }\end{array}$ & $\begin{array}{c}\text { Share of } \\
\text { GDP, \% }\end{array}$ & $\begin{array}{c}\text { Total } \\
\text { volume, } \\
\text { billion } \\
\text { rubles }\end{array}$ & $\begin{array}{c}\text { Share of } \\
\text { GDP, \% }\end{array}$ \\
\hline Revenue & 6291.5 & 8.6 & 7146.7 & 9.0 & 7528.8 & 9.7 \\
\hline Expenditure & 6425.6 & 8.8 & 7769.8 & 9.8 & 6539.1 & 9.5 \\
\hline Deficit & 134.1 & 0.2 & 623.1 & 0.8 & - & - \\
\hline
\end{tabular}

* The table is formed according to Rosstat [10].

Table 2

Absolute and relative deviation of the dynamics of revenue and expenditure of the Pension Fund of the Russian Federation in 2014 and 2016

\begin{tabular}{|c|c|c|c|c|c|c|c|c|}
\hline \multirow[b]{3}{*}{ Indicator } & \multicolumn{4}{|c|}{ Absolute deviation } & \multicolumn{4}{|c|}{ Growth rate, $\%$} \\
\hline & \multicolumn{2}{|c|}{ In 2015} & \multicolumn{2}{|c|}{ In 2016} & \multicolumn{2}{|c|}{ In 2015} & \multicolumn{2}{|c|}{ In 2016} \\
\hline & $\begin{array}{c}\text { Total } \\
\text { volume, } \\
\text { billion } \\
\text { rubles }\end{array}$ & $\begin{array}{c}\text { Share } \\
\text { of } \\
\text { GDP, } \\
\%\end{array}$ & $\begin{array}{c}\text { Total } \\
\text { volume, } \\
\text { billion } \\
\text { rubles }\end{array}$ & $\begin{array}{l}\text { Share of } \\
\text { GDP, \% }\end{array}$ & $\begin{array}{c}\text { Total } \\
\text { volume, } \\
\text { billion } \\
\text { rubles }\end{array}$ & $\begin{array}{c}\text { Share } \\
\text { of } \\
\text { GDP, } \\
\%\end{array}$ & $\begin{array}{c}\text { Total } \\
\text { volume, } \\
\text { billion } \\
\text { rubles }\end{array}$ & $\begin{array}{c}\text { Share } \\
\text { of } \\
\text { GDP, } \\
\%\end{array}$ \\
\hline Revenue & 855.2 & 0.4 & 382.1 & 0.7 & 113.6 & 104.6 & 105.3 & 107.7 \\
\hline Expenditure & 1344.2 & 1 & -1230.7 & -0.3 & 120.9 & 111.4 & 84.2 & 96.9 \\
\hline Deficit & 489 & 0.6 & -623.1 & -0.8 & 464.5 & - & - & - \\
\hline
\end{tabular}

* The table is formed by the authors. 
Table 3

Expenditure structure of the Pension Fund of the Russian Federation in 2014 and 2016, \%

\begin{tabular}{|l|c|c|c|c|c|c|c|}
\hline & \multirow{2}{*}{$\begin{array}{l}\text { Expenditure } \\
\text { Eension provision }\end{array}$} & 2014 & 2015 & 2016 & \multicolumn{2}{c|}{ Change (+.-), \% } & \multicolumn{2}{c|}{ Growth rate, \% } \\
\cline { 5 - 8 } & 82.3 & 83.2 & 87.1 & 0.9 & 3.9 & 101.1 & 104.7 \\
\hline $\begin{array}{l}\text { Expenditure on } \\
\text { social security, } \\
\text { family protection, } \\
\text { etc. }\end{array}$ & 15.8 & 15.6 & 10.1 & -2 & -5.5 & 98.7 & 64.7 \\
\hline Other expenditure & 1.9 & 1.2 & 2.8 & -0.77 & 1.6 & 63.7 & 233 \\
\hline Expenditure, total & 100 & 100 & 100 & 0 & 0 & 100 & 100 \\
\hline
\end{tabular}

* The table is formed according to the pension Fund of the Russian Federation [8].

Table 4

Revenue structure of the Pension Fund of the Russian Federation in 2014 and 2016, \%

\begin{tabular}{|l|c|c|c|c|c|c|c|}
\hline \multirow{2}{*}{ Revenue } & \multirow{2}{*}{2014} & \multirow{2}{*}{2015} & 2016 & \multicolumn{2}{c|}{$\begin{array}{c}\text { Absolute deviation, } \\
\%\end{array}$} \\
\cline { 5 - 9 } & & & & in 2015 & in 2016 & in 2015 & in 2016 \\
\hline Insurance premium & 51.9 & 56.8 & 61.5 & 4.6 & 4.7 & 108.8 & 108.3 \\
\hline $\begin{array}{l}\text { Transfers from the } \\
\text { federal budget }\end{array}$ & 47.9 & 42.5 & 37.6 & -5.4 & -4.9 & 88.7 & 88.5 \\
\hline Other revenue & 0.5 & 0.7 & 0.9 & 0.2 & 0.2 & 140 & 128.6 \\
\hline Revenue, total & 100 & 100 & 100 & 0 & 0 & 100 & 100 \\
\hline
\end{tabular}

* The table is formed according to the Pension Fund of the Russian Federation [8].

Table 5

The share of federal budget funds in the budget revenues of the Pension Fund of the Russian Federation in 2014 and 2016., \%* 
550

\begin{tabular}{|c|c|c|c|c|c|c|}
\hline & $\begin{array}{c}\text { PFR } \\
\text { budget, } \\
\text { billion } \\
\text { rubles }\end{array}$ & $\begin{array}{c}\text { Proportion, } \\
\%\end{array}$ & $\begin{array}{c}\text { PFR } \\
\text { budget, } \\
\text { billion } \\
\text { rubles }\end{array}$ & $\begin{array}{c}\text { Proportion, } \\
\%\end{array}$ & $\begin{array}{c}\text { PFR } \\
\text { budget, } \\
\text { billion } \\
\text { rubles }\end{array}$ & $\begin{array}{c}\text { Proportion, } \\
\%\end{array}$ \\
\hline Total revenue & 6291.5 & 100 & 7146.7 & 100 & 7528.8 & 100 \\
\hline \multicolumn{7}{|l|}{ among them: } \\
\hline $\begin{array}{l}\text { Inter-budget transfers } \\
\text { from the federal budget, } \\
\text { total }\end{array}$ & 2425.8 & 35.9 & 3204.7 & 36.5 & 3410.9 & 37.9 \\
\hline $\begin{array}{l}\text { including: } \\
\text { obligations of the } \\
\text { Russian Federation }\end{array}$ & 2174.3 & 34.2 & 2514.8 & 34.7 & 3110.4 & 35.8 \\
\hline $\begin{array}{l}\text { For valorization of } \\
\text { pension rights }\end{array}$ & 600.7 & 9.1 & 651.33 & 9.2 & 685.45 & 7.2 \\
\hline $\begin{array}{l}\text { For federal social } \\
\text { retirement supplement }\end{array}$ & 45.32 & 0.6 & 47.89 & 0.7 & 50.65 & 0.4 \\
\hline $\begin{array}{l}\text { for compensation of PFR } \\
\text { budget revenue }\end{array}$ & 298.6 & 4.3 & 302.4 & 4 & 312.58 & 4.1 \\
\hline $\begin{array}{l}\text { For monthly pension } \\
\text { payment }\end{array}$ & 389.8 & 3.2 & 401.74 & 3.3 & 419.37 & 2.9 \\
\hline For state pension & 375.49 & 3.1 & 396.71 & 3.2 & 425.17 & 2.6 \\
\hline $\begin{array}{l}\text { For provision of } \\
\text { maternity (family) } \\
\text { capital }\end{array}$ & 312.97 & 1.9 & 324.30 & 3.2 & 332.46 & 1.5 \\
\hline $\begin{array}{l}\text { For co-financing of the } \\
\text { formation of pension } \\
\text { savings }\end{array}$ & 99.23 & 1.3 & 99.84 & 1.3 & 110.97 & 1.1 \\
\hline $\begin{array}{l}\text { For other payments } \\
\text { (northerners' } \\
\text { transportation, measures } \\
\text { of social support, etc.) }\end{array}$ & 22.83 & 0.9 & 25.70 & 0.5 & 28.40 & 0.4 \\
\hline
\end{tabular}




\begin{tabular}{|l|l|l|l|l|l|c|}
\hline $\begin{array}{l}\text { For ensuring PFR fiscal } \\
\text { balance (compensation } \\
\text { insurance of retirement } \\
\text { pension) }\end{array}$ & 382.2 & 5.5 & 400.63 & 5.9 & 412.56 & 6.1 \\
\hline
\end{tabular}

* The table is formed according to the Pension Fund of the Russian Federation [8].

Table 6

Revenue and expenditure of the federal budget

and the Pension Fund of the Russian Federation in 2014 and 2016, \%.

\begin{tabular}{|l|c|c|}
\hline \multicolumn{1}{|c|}{ Budget figures } & $\begin{array}{c}\text { Federal budget } \\
\text { (on 1 December 2016) }\end{array}$ & $\begin{array}{c}\text { PFR budget } \\
\text { (on 1 December 2016) }\end{array}$ \\
\hline Revenue & 0.7 & 99.9 \\
\hline Expenditure & 98.7 & 100.4 \\
\hline
\end{tabular}

* The table is formed according to Rosstat [10].

Table 7

Number of working pensioners in Russia in 2014 and 2016, thousand people*

\begin{tabular}{|c|c|c|c|c|c|c|c|}
\hline \multirow{3}{*}{ Indicator } & \multirow{3}{*}{2014} & \multirow{3}{*}{2015} & \multirow{3}{*}{2016} & \multicolumn{4}{|c|}{ Change } \\
\hline & & & & \multicolumn{2}{|c|}{$\begin{array}{l}\text { Absolute }(+/-) \\
\text { thousand rubles }\end{array}$} & \multicolumn{2}{|c|}{ Growth rate, $\%$} \\
\hline & & & & in 2015 & in 2016 & in 2015 & in 2016 \\
\hline $\begin{array}{l}\text { The total } \\
\text { number of } \\
\text { pensioners in the } \\
\text { Russian } \\
\text { Federation, } \\
\text { thousands }\end{array}$ & 41554.6 & 42145.2 & 43941.9 & 590.6 & 1796.7 & 101.4 & 104.2 \\
\hline $\begin{array}{l}\text { The total } \\
\text { number of } \\
\text { working } \\
\text { pensioners in the }\end{array}$ & 14758 & 15327 & 16124 & 749 & 797 & 103.8 & 105.2 \\
\hline
\end{tabular}




\begin{tabular}{|l|l|l|l|l|l|l|l|}
\hline $\begin{array}{l}\text { Russian } \\
\text { Federation, } \\
\text { thousands }\end{array}$ & & & & & & & \\
\hline $\begin{array}{l}\text { The share of } \\
\text { working } \\
\text { pensioners to the } \\
\text { total number, } \%\end{array}$ & 35.5 & 36.4 & 36.7 & 0.9 & 0.3 & 102.5 & 100.8 \\
\hline
\end{tabular}

* The table is formed according to the Pension Fund of the Russian Federation

Table 8

Comparative calculation of individual pensions in the Far North and other regions of the Russian Federation, rub.*

\begin{tabular}{|c|c|c|}
\hline \multirow[t]{2}{*}{ Calculation } & \multicolumn{2}{|c|}{ Total amount } \\
\hline & The Far North & Other regions \\
\hline Pension income amount & 1286.67 & 1102.86 \\
\hline Notional pension capital by 1 January 2002 & 210840.84 & 164520.72 \\
\hline $\begin{array}{l}\text { Notional pension capital with incomplete work } \\
\text { service }\end{array}$ & 136695.14 & 106664.27 \\
\hline Indexed pension capital by 31 December 2014 & 767518.18 & 598898.53 \\
\hline $\begin{array}{l}\text { Determination of retirement pension on reaching } \\
\text { retirement age (based on the amount of valorization) }\end{array}$ & 456.86 & 356.49 \\
\hline $\begin{array}{l}\text { Insurance component of insurance contributions } \\
\text { according to an individual account }\end{array}$ & 2265.44 & 2265.44 \\
\hline $\begin{array}{l}\text { Insurance pension on reaching retirement age by } 31 \\
\text { December } 2014\end{array}$ & 5768.01 & 4998.51 \\
\hline The pension point by: & & \\
\hline - 1 January 2015 & 64.10 & 64.10 \\
\hline - 1 February 2016 & 74.27 & 74.27 \\
\hline - 1 February 2017 & 78.28 & 78.28 \\
\hline
\end{tabular}




\begin{tabular}{|l|c|c|}
\hline $\begin{array}{l}\text { Amount of individual pension coefficient for the } \\
\text { periods that took place: }\end{array}$ & 89.985 & 77.979 \\
\hline - until 1 January 2015 & 7926.99 & 6956.90 \\
\hline Insurance pension by 23 March 2017 & 15104.40 & 11762.01 \\
\hline $\begin{array}{l}\text { Insurance pension on reaching retirement age since } \\
23 \text { March 2017 }\end{array}$ & & \\
\hline Including: & 7207.67 & 4805.11 \\
\hline Fixed amount & & \\
\hline
\end{tabular}

* The table is formed by the authors.

Table 9

Comparison of individual pensions of I. and R. in case of refusal to retire on reaching retirement age, rub. *

\begin{tabular}{|l|c|c|c|c|}
\hline \multicolumn{1}{|c|}{ Indicator } & Individual I. & Individual P. & $\begin{array}{c}\text { Absolute } \\
\text { deviation, } \\
+/-\end{array}$ & $\begin{array}{c}\text { Growth } \\
\text { rate, \% }\end{array}$ \\
\hline $\begin{array}{l}\text { Pension accrued at the time of } \\
\text { maturity }\end{array}$ & 15911.72 & 15104.40 & -807.32 & 94.9 \\
\hline $\begin{array}{l}\text { Rejection of pension in: } \\
3 \text { years (19\% performance bonus) }\end{array}$ & 19057.07 & 16486.14 & -2570.93 & 86.5 \\
\hline 5 years (37 \% performance bonus) & 21794.26 & 17058.09 & -4736.17 & 78.3 \\
\hline
\end{tabular}

* The table is formed by the authors.

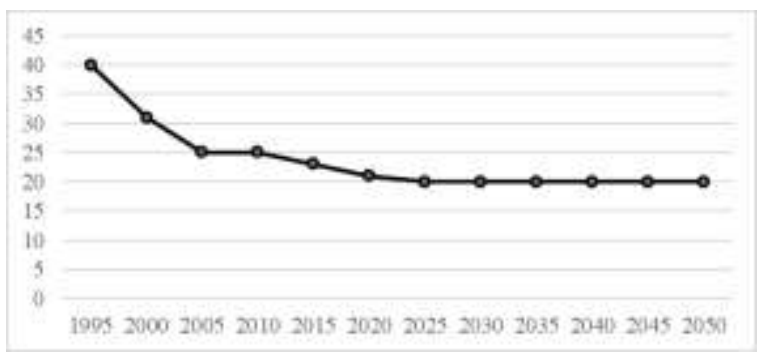

Figure 1. Dynamics of replacement rate of the average wage by the average pension in Russia, $\%$ [8]

\section{Discussion}


The analysis of revenue and expenditure of the Pension Fund of the Russian Federation shows positive dynamics over the period considered (table 1-2). So, total revenues amounted to 7528.8 billion rubles in 2016, it was $5.3 \%$ over the previous year; the expenditure of the Pension Fund decreased by $15.8 \%$ and amounted to 6539.1 billion rubles against 7769.8 billion rubles in 2015, which provided the surplus of the Pension Fund in the amount of 989.7 billion rubles. Throughout 2014 and 2015, there is a funding gap in the Pension Fund, and revenue exceeded expenditure by $15.14 \%$ in 2016 .

The share of the Fund's revenues in gross domestic product (GDP) was $8.6 \%$ in 2014 and increased to $9.7 \%$ in 2016, while the share of the Pension Fund's expenditure in GDP amounted to $9.5 \%$ in 2016 against $9.8 \%$ in 2015 .

Three groups of expenditure were identified in the analysis of PFR expenditure structure (table 3 ). The first group includes the expenditure of state pension provision; it differs by the large share over total expenditure equal to 82.3 $\% ; 83.2 \%$ and $87.1 \%$, and the growth rate is equal to $104.7 \%$ in 2016 . The second group includes social security expenditure, the share of which decreased from 2014 to 2016. Thus, in the reporting year, the share of social security expenditure is $10.1 \%$, which is $5.5 \%$ less than in 2015; the rate of decline is $64.7 \%$. Other expenditure, as the third group, accounted for a small share in the total expenditure pattern in 2014 and 2016 , equal to $1.9 \% ; 1.2 \%$ and $2.8 \%$ respectively.

The revenue structure of the Pension Fund of the Russian Federation is represented by insurance premiums, transfers from the federal budget and other benefits (table 4). Analyzing the revenue structure of the Pension Fund, it should be noted that the share of insurance premiums in the total revenue of the Pension Fund increased from $51.9 \%$ in 2014 to $61.5 \%$ in 2016.

At the same time, a major share of pension payments (about $37 \%$ of the Pension Fund's expenditure in 2016) is financed by transfers from the federal budget (table 5), which indicates a high degree of dependence of PFR on the federal budget and its implementation on revenue and expenditure. Most of PFR budget was financed by obligations of the Russian Federation, so it amounted to 2174.3 billion rubles in 2014 and 3110.4 billion rubles in 2016, as well as it amounted to 600.7 billion rubles in 2014 
due to valorization of pension rights, and 685.45 billion rubles in 2016 .

The highest degree of dependence of the Russian pension system on the federal budget is proved by the data of the Ministry of Finance of the Russian Federation on the budget execution of PFR in 2016. By 1 December 2016, the budget of PFR was implemented for revenue by $99.9 \%$ and for expenditure by $100.4 \%$. Therefore, in late 2016, the budget was not executed by $0.5 \%$ (table 6 ).

Thus, spending a significant share of GDP on pension provision, the pension system of Russia creates a low level of pensions, for example, the average retirement pension was 11783.29 rubles in 2015, and it amounted to 13132 rubles in 2016.

The main reasons for insufficient performance of the pension system of the Russian Federation, manifested in the low level of pension provision of citizens of the Russian Federation, are:

- high dependence of the pension system of the Russian Federation on the federal revenue, which is related to the large share of transfers of the federal budget in total income of PFR;

- low level of insurance premiums in PFR in business structures, due to the fact that the nominal rate of insurance premiums in PFR of the Russian Federation is $22 \%+10 \%$ of the insurance premium rate, if the size of the base for the calculation of insurance contributions from the employer is greater than the established value. Considering the fact that in the period of economic recession and financial crisis, the profit and compensation of employees are reduced, it is possible to assume a reduction of insurance contributions in 2017 and potentially; - lack of effective mechanisms of the state management system aimed at increasing the legalization of employment and payment of insurance premiums;

- negative balance of the number of persons employed in the economy and paying pension contributions and the number of pension recipients, which is caused by the unfavorable demographic situation. According to Rosstat's forecasts, the number of labor force will decline by 11 million in 2030, and the number of people of retirement age is expected to reach 9 million, the ratio between the number of employees for whom contributions are paid to the pension system and the number of pensioners will be reduced from 1.5: 1 in 
2016 to $1.4: 1$ - in 2020, 1.05:1 - in 2030, $0.97: 1$ - in 2040, 0.93:1 - in 2050.

The number of employed in the economy during the period from 2014 to 2016 increased steadily in the population structure as well as the demographic burden on the population of working age. So, if the employment to population ratio amounted to $105.7 \%$ in 2014 and 2015, then it was $107.4 \%$ in 2016. The growing number of elderly people is ensured by reducing mortality by 21.332 people and increasing life expectancy of persons related to this age group. The average life expectancy of Russian citizens reached 71.4 years (65.9 years for men and 76.7 years for women) in 2015. This figure increased by 8.5 months, reaching 72.1 years. Female life expectancy exceeded 77.3 years, and male life expectancy approached 67 years [14];

- the retirement age is low in comparison with other countries with market economy (women -55 years and men -60 years), which, coupled with the number of early retirees leads to a large share of pensioners in the total population of the Russian Federation.

In addition, pension provision, as a result of activities of pension system, is influenced by the territorial division of the Russian Federation into two types: regions of the Far North; other regions of the Russian Federation.

This affects the level of pension provision.

For example, in the Far North, the average pension is 3.000 rubles higher than in other areas. This is due to the consumer price level and as a consequence of the subsistence minimum. In addition, there is the increase in consumer prices in throughout the territories of the Russian Federation. Therefore, the pension can also be increased by its annual indexation depending on the level of inflation in the country and the consumer price index.

Two factors also have a significant impact on the performance of the Pension Fund: the increase in the number of working pensioners and the new procedure for calculating the pension for compulsory pension insurance, introduced from 1 January 2015.

Thus, the growth in the number of working pensioners progresses every year. If their number was about 14.8 thousand people in 2014, then it amounted to more than 16 thousand people in 2016. 
The research has shown that the main reason for continued employment for $70 \%$ of pensioners is the need to improve their material welfare, and $30 \%$ of them have the desire to help their children and relatives.

New pension calculation, consisting of points-based system, suggests that when recalculating the pension, a working pensioner may be additionally credited no more than three pension points, while non-working points are based on the indexation and level of inflation for the previous year [14]. Russian Prime Minister Dmitry Medvedev instructed the Government of the Russian Federation to consider the issue of return to the pension indexation for working pensioners, which will be resolved no earlier than 2020. In 2016, the maximum increase for the working pensioner was 222.81 rubles; that was 4 \% (18.42 rubles) higher than in 2015, when the value of this increase was equal to 214.23 rubles.

From 2016 to 2019, whatever the choice of the pension option in the system of mandatory pension insurance, all citizens are formed pension rights only for insurance pension, based on the total amount of insurance contributions. Therefore, the maximum value of the annual individual pension coefficient is the same for any option of pension formation.

The timeframe for the insurance pension on reaching retirement age impacts on the calculated points. If the employee applies later, continuing his employment, then the insurance pension is increased by the corresponding coefficients for each year of late application of the pension scheme (the refusal of assessed contributions). For example, if an employed citizen applies for a pension in 5 years after reaching the retirement age, the insurance pension increases by $36 \%$, and the amount of personal pension coefficients - by $45 \%$, in the case of appeal in ten years, its payment will increase in 2.11 times, and the amount of personal pension coefficients in 2.32 times.

From 1 January 2015, the Federal Law No. 400-FZ "On Insurance Pensions" of 28 December 2013 came into force, according to which the calculation of insurance pensions is made in accordance with article No. 15 of the Federal Law based on the individual pension coefficient $[1,2,3,4$, $5]$.

The pension scheme is considered on the example of two 
individuals living in the Far North. So, the calendar work experience of the first individual R. is 30 years, in the Far North -28 .

According to the application of 28 February 2017, the citizen R. has an insurance pension on reaching retirement age in accordance with paragraph 10 of part 1 of article 30 of the Federal law № 400-FZ of 28 December 2013 "On Insurance Pensions" from 23 March 2017, it is noted that for persons living in the Far North as of 1 January 2002 and having regional coefficients, the ratio of the average monthly earnings of the insured person to the average monthly wage in the Russian Federation is considered in the following amounts: it is less than 1.4 for persons living in districts and areas, where the salary of employees is set to the district coefficient of up to 1.5.

For example, in the territory of Murmansk, equated to the Far North, an established regional coefficient -1.4 is applied to determine pensions [6].

Table 8 presents a comparative pension calculation in the far North and other regions of the Russian Federation.

The second individual is a citizen I., having her average salary up to 70 thousand rubles over the past 7 years, but also two adult children.

Suppose that I., having relatively higher revenue and $\mathrm{R}$. with a lower income applied for an insurance pension, respectively, in three years and five years (table 9), thus the citizen I. has the right to apply for insurance pension award in 53, then for later appeal for pension premium coefficient for insurance pension is 1.24 , for the defined benefit pension scheme is 1.19 .

The insurance pension in this case will be:

$116.37 * 1.24 * 78$ rub. 58 kop. +4.805 rub. 11 kop. $* 1.19+2.000=$ 19.057 rub.07 kop.

If I. applies for insurance pension upon reaching retirement age five years after the right to it in 55 , then the insurance pension will be:

$116.37 * 1.45 * 78$ rub. 58 kop. +4.805 rub. 11 kop. $* 1.36+2.000=$ 21.794 rub. 26 kop.

If an individual $R$. applies for the insurance pension upon reaching retirement age three years after the right to it in 58 years, the insurance pension will be:

$89.985 * 1.24 * 78$ rub. 58 kop. +4.805 rub. 11 kop. $* 1.19+2.000=$ 16.486 rub. 14 kop. 
If citizen R. will apply for the insurance pension upon reaching retirement age five years after the right to it in 60 years, the amount of insurance pension will be:

$89.985 * 1.45 * 78$ rub. 58 kop. +4.805 rub. 11 kop. * $1.36+2.000=$ 17.058 rub. 09 kop.

One of the important factors of social and economic security of each state, including the Russian Federation, is an effective pension system. The working age population wants to be sure that when the retirement age is reached, pension payments will be sufficient to ensure a decent standard of living. In modern conditions, the demographic situation in Russia is characterized by such trends as low birth rate and ageing population, which leads to an increase in the share of people of working age and pensioners. If these trends continue, Russia may face the fact that a large share of the economically active population will consist of pensioners, and the rate of progressive development of the Russian economy will depend on the effective demand of this particular category of population. As a result, the formation of an adequate pension system and pension provision that meets the needs of the population in the non- productive age for a high standard of living is the main factor of economic security of Russia. For that period, there are two main problems of the pension system - a deficit of the PFR budget and a low level of pension provision.

The problem of the budget deficit can be really solved if the age pension threshold is raised. At the same time, the increase of the retirement age should reduce social tension in society, which is solved by increasing the pension [12, 13].

The low level of pension provision implies a very low replacement ratio (figure 1).

In order to increase the financial wealth of pensioners, reduce poverty in this socio-economic group of the population, the public policy of indexation of the retirement pension and its approximation to subsistence minimum of a pensioner is implemented, as described in the pension legislation, the deficit of the pension fund can be constantly increase. In this case, both the base and the insurance part of the retirement pension will be at a loss. In general, the deficit of the distribution part of the pension in the process of its possible further increase is projected to increase to $3.07 \%$ of GDP in 2050 . The 
loss of the insurance and base parts of the retirement pension can be developed in different ways.

According to the Pension Fund's forecasts, if the deficit of the base part of the retirement pension will be systematically increased from 0.37 to $2.85 \%$ of GDP, the deficit of the insurance part of the pension is projected to slowly decline to $0.28 \%$ of GDP in 2050.

Thus, the following measures are proposed to solve the problems of pension development and formation of mechanisms for functioning of pension schemes:

- to increase the level of pension provision for people of retirement age and eliminate poverty among them;

- to develop insurance-based principles for the provision of pensions;

- to change the sources of funding of the mandatory pension insurance system;

- create conditions for the acquisition of pension rights from insured persons in the required amount;

- to increase the cumulative component of the pension fund;

- increase the retirement age;

- create a system of retraining for persons of pre-retirement age;

\section{0}

- to create a system of non-state pensions on a voluntary basis and having insurance guarantees from the state.

The implementation of these measures can ensure the growth of pension provision for pensioners and form the prerequisites for obtaining decent pensions for working citizens. Therefore, the creation of legislative and regulatory basis for pension system's functioning, which will improve the results of the implementation of the pension reform in Russia should be the main task of the government of the Russian Federation.

The measure to increase the age of retirement is the most significant and discussed of all the proposed measures.

The retirement age in most countries of the world is different, and there are their own retirement rules and principles of funds.

Thus, there are three main characteristics of the pension system:

1) retirement age;

2) the amount of the pension;

3) methods of formation of pension savings.

The first characteristic, the retirement age varies from country to country, depending on two factors:

- social and economic situation; 
- life expectancy, which is called life expectancy at birth in statistical reporting.

The second characteristic is the amount of the pension, which is different everywhere.

The third characteristic is the formation of pension savings on the basis of funds, which is carried out by the following methods:

1) according to the individual and cumulative plan;

2) using the distribution system based on: a) pension taxes; b) general tax revenues.

The variation in retirement age depends on gender and life expectancy in most countries of the world $[18,19]$.

The maximum retirement age of 70 years for both men and women is observed in Japan, with an average life expectancy of 82.1 years. The retirement age in the United Kingdom is 68 for men and 60 for women; life expectancy in this country is 79 .

In countries such as Denmark, Norway, Germany, the retirement age for the entire population is 67 with an average life expectancy of 79 .

Men and women of the USA, Canada, Spain, and Sweden retire at the age of 65; an average life expectancy in these countries is about 80 .

Men and women of the USA, Canada, Spain, and Sweden retire at the age of 65; the average life expectancy in these countries is about 80 .

Men of Switzerland, Armenia and Belgium retire at the same age of 65 . Moreover, the life expectancy in Armenia is 72.7 , which is significantly lower than the life expectancy in Switzerland and Belgium, equal to 80.9 and 79.2, respectively. However, women in Switzerland, Armenia and Belgium retire at the age of 64,63 and 62 , respectively.

In Italy and France, the retirement age for men is 67 , for women -65 with a life expectancy of just over 80.

In Kazakhstan and Lithuania, the retirement age for men is 63 and 62.5, for women -58 and 58.5 respectively, with an average life expectancy of 67.9 in Kazakhstan and 74.9 in Lithuania.

In countries such as Hungary, the Czech Republic, Azerbaijan and Moldova, the retirement age for men is 62; women in Hungary and the Czech Republic retire at the same age, and Moldova and Azerbaijan - 57. Life expectancy in Hungary, the Czech 
Republic, Azerbaijan and Moldova ranges from 70.8 to 76.7 .

Men in Ukraine, Belarus and Uzbekistan retire at the age of 60 , and women's retirement age is 55 , and the average life expectancy is about 70 .

Current trends in the variation of retirement age are that in 2015-2016 the retirement age in different countries began to increase. The reasons were the ongoing global crisis, the shortage of funds in the budget of most countries.

Expected changes in the retirement age will occur in countries such as Ukraine, which promises to raise the retirement age for women to 60 by 2021; Kazakhstan, where the retirement age for men and women is 63 in 2018; the United States plans to increase the retirement age from 65 to 69 .

According to international experts, there is no optimal retirement age and no ideal pension system.

As an example of an almost ideal and exemplary pension system is the UK. There are three types of pension provision as in many countries:

- state pension;

- superannuated pension;

- non-state pension.

Basic state pension is paid to all British citizens when they reach the
562

retirement age. Pensions are fixed and do not depend on experience or other factors, and they are paid from tax revenues. For all pensioners who have certain seniority, there is another option - a superannuated pension, depending on the experience and wages. But a large amount can be obtained in the form of a non-state pension, the amount of which is determined individually by the employee. Such pension is formed both by the employee and his employer [11].

Participation in private systems is stimulated by a number of significant tax benefits.

Features of pension systems consist in the use of different methods of pension savings formation. The most common is the combination of them. Three methods are used as the basis for all systems.

The essence of the first method, an individual and cumulative, is that the working citizen transfers part of his earnings to the Pension Fund, either by himself or by the employer. Further, the old-age pension is formed by these savings.

The second (a distributive method) is based on pension taxes; employees do not save their money to form future pensions. Part of their 
earnings is directed to the payment of pensions to existing pensioners in the current period. Accordingly, currently working citizens after retirement will receive their benefit payments in the form of pensions financed by the contributions from the wages of working compatriots.

The third method (based on general taxes) is that pension is paid from funds that are received by the Tax Fund.

Currently, citizens of Denmark are paid high pension benefit in the amount of $\$ 2.800$ per month; the amount of $\$ 1.900$ to 1.164 is given to citizens of Finland, Norway, Israel, Germany, Spain, United States; citizens of Switzerland, Sweden, Japan, UK, France, Canada and Italy have less than $\$ 1.000$ but more than $\$ 500$ per month; the citizens of Hungary, Poland, China, Bulgaria, Lithuania, Latvia, Kazakhstan, Azerbaijan, Belarus and Ukraine receive a pension between $\$ 500$ and $\$ 100$; and less than $\$ 100$ per month is given to the pensioners of Argentina, Moldova, Uzbekistan and Georgia.

Thus, the difference between the highest and the lowest pension is 70 times.

\section{Conclusion.}

The study found that the budget of PFR, consisting of revenue and expenditure parts is formed under the equality of income and expenses. They interact only with payments of different types of employment pensions and state pension provision, and other benefits and payments are not included.

Budget expenditure depends on the number of pensioners and the average pension, but does not include delivery costs and pension provision.

The average pension depends on the factors that characterize the growth of the number of persons employed in the economy, the number of pensioners, the share of informal employment, donations from the federal budget, the share of wage fund in GDP, the effective premium rates.

The list of measures proposed for the formation of a better pension system in the Russian Federation corresponds to the state policy on the transition to a new pension system, which aims to use individual and cumulative method and establish a mechanism for its indexation.

The practical significance of this study is to use the experience of foreign countries to increase the retirement age and improve the pension system, the 
establishment of a combined pension system based on the use of individual and cumulative and distributive methods, one of which is based on pension taxes, and the other - on the general taxes.

\section{References}

O gosudarstvennom pensionnom obespechenii v Rossijskoj Federacii: federalnyj zakon ot 15 dekabrja $2001 \mathrm{~g}$. №166-FZ [About the state provision of pensions in the Russian Federation: Federal Law No. 166-FZ of 15 December 2001 [Adopted by the State Duma on November 30, 2011. Approved by the Federation Council on December 5, 2001] // Legislation Bulletin of the Russian Federation. - December 17, 2001. - No. 17. - Art. 4834.

$\mathrm{O}$ trudovyh pensijah $\mathrm{v}$ Rossijskoj Federacii: federal'nyj zakon ot 17 dekabrja 2001 g. №173-FZ [On labour pensions in the Russian Federation: Federal Law No. 173-FZ of 17 December 2001 [Adopted by the State Duma on November 30, 2011. Approved by the Federation Council on December 5, 2001] // Legislation Bulletin of the Russian Federation. - December 20, 2001. - No. 17. - Art. 197
O strahovyh pensijah: federalnyj zakon ot 28 dekabrja 2013 g. №400 FZ [On Insurance Pensions: Federal Law No. 400-FZ of 28 December 2013 [Adopted by the State Duma on December 23, 2013. Approved by the Federation Council on December 25, 2013] // Legislation Bulletin of the Russian Federation. - July 6, 2015. - No. 77. Art. 3968.

O nakopitelnoj pensii: federalnyj zakon ot 28 dekabrja 2013 g. №424 FZ [On Cumulative Pensions: Federal Law No. 424-FZ of 28 December 2013 [Adopted by the State Duma on December 23, 2013. Approved by the Federation Council on December 25, 2013] // Legislation Bulletin of the Russian Federation. - December 30, 2013. - No. 52. - Art. 6989.

O porjadke finansirovanija vyplat za schet sredstv pensionnyh nakoplenij: federalnyj zakon ot 30 nojabrja $2011 \mathrm{~g}$. №360-FZ [On Procedure of Financing of Payments from Pension Funds: Federal Law No. 360-FZ of 30 November 2011 [Adopted by the State Duma on November 23, 2013. Approved by the Federation Council on November 25, 2013] // Legislation Bulletin of the Russian Federation. - December 25, 2011. - No. 50. - Art. 5447. 
Postanovlenie

gosudarstvennogo

komiteta soveta ministrov SSSR po voprosam truda i zarabotnoj plate i prezidiuma [Resolution of the state Committee of the Council of Ministers of the USSR on labor and wages and the Presidium (No.380/P-18)].

Baranova E. Osobennosti razvitija pensionnogo obespechenija $\mathrm{v}$ Rossii $\mathrm{V}$ XVIII-XIX vv. [Features of the development of pension provision in Russia in XVIII-XIX centuries]: Abstract for the Candidate of Juridical Sciences degree. - Krasnodar, 2010. - 30 p.

Pensionnyj fond Rossijskoj Federacii [Pension Fund of the Russian Federation [Electronic resource] / Official website. - Access mode: http://www.pfrf.ru/files/id/press_center/ godovoi_otchet/Annual_report_2016_3. pdf, free.

Ermakov D. Pensionnoe obespechenie federal'nyh gosudarstvennyh grazhdanskih sluzhashhih $\mathrm{v}$ rossijskoj federacii [Pension provision of federal civil servants in the Russian Federation] / D. Ermakov // Insurance business, 2012. - No. 7 (234). - P. 10-21.

Kruchek I. Socialnye pensii kak vid gosudarstvennyh pensij s tochki zrenija principov prava social'nogo obespechenija [Social pensions as a type of state pensions in terms of principles of social security law [Electronic resource] / I. Kruchek, E. Bernatas // Scientific observer (www.tavr.science) № 11(16) November 2016. - P. 1-5. - Access mode:

http://tavr.science/stat/2016/11/14-

Kruchek-Bernatas.pdf, free.

Pensionnyj vozrast $\mathrm{V}$ stranah mira [Retirement age in the world [Electronic resource] / Official website. TASS. News agency. - Access mode: http://tass.ru/info/5291492, free.

Pensionnaja reforma $\mathrm{v}$ Rossii [Pension reform in Russia [Electronic resource] / Pensija znajte svoi vozmozhnosti [Pension. Know your . - Available at: http://pensiya.molodajasemja.ru/reforma, free.

Pravitelstvo predlozhilo perehodnyj period dlja pensionnoj reformy [The government has proposed a transition period for pension reform [Electronic resource] / RBK - Access mode: https://www.rbc.ru/economics/14/06/20 18/5b222c519a794745cc8279f0http://pe nsiya.molodaja-semja.ru/reforma, free. Regiony Rossii: social'nojekonomicheskie pokazateli [Regions of Russia: Social-economic 
indicators]. 2017. - Rosstat. -Moscow: Statistics of Russia, 2017. - 900 p.

Silchuk A. Povyshenie finansovoj ustojchivosti pensionnoj sistemy Rossijskoj Federacii [Ensuring of financial stability of the pension system of the Russian Federation: Abstract for the Candidate of Economic Sciences degree [Electronic resource] / A. Silchuk - Access mode: http:/guu.ru/files/dissertations/2016/06/ silchuk_a_a/autoreferat.pdf, 2016, free. Silchuk A. Sil'nye i slabye storony strahovoj i nakopitel'noj component $\mathrm{V}$ sisteme objazatel'nogo pensionnogo strahovanija [Strengths and weaknesses of the insurance and funded component in the system of mandatory pension insurance] / A. Silchuk // Economics and entrepreneurship. - 2016. - № 6. - P. 1822.

Silchuk A. Jeffektivnost' sistemy objazatelnogo pensionnogo strahovanija dlja zastrahovannogo lica [Effectiveness of mandatory pension insurance for the insured person] / A. Silchuk // Vestnik Universiteta (State university of management). - 2016. - No. 3. - P. 2427.

Fast Facts \& Figures About Social Security, 2015. SSA. [Electronic resource] Available at:
566

https://www.ssa.gov/policy/docs/chartb ooks/fast_facts/2015/fast_facts15.pdf Plug. from the screen.

Stewart, F. Benefit Security Pension Fund Guarantee Schemes, OECD Working Papers Insurance and Private Pensions [Electronic resource], 2007. No. 5. - doi:10.1787/260604113335 OECD. - Available at http://www.oecd.org/finance/privatepensions/37977335.pdf- Plug. from the screen.

Pension Markets in Focus, 2017 edition [Electronic resource]. - Available at: http://www.oecd.org/pensions/privatepensions/Pension-Markets-in-Focus2017.pdf. - Plug. from the screen.

Williams, M. Questions Answered About Pension Plans- [Electronic resource], 2012. - No. 5. - The New York Times, Available at: https://www.nytimes.com/2012/11/05/b ooming/questions-answered-aboutpension-plans.html

Allen, Everett T., Joseph J. Melone, Jerry S. Rosenbloom, and Jack L. VanDerhei. 1997. Pension Planning: Pension, Profit-Sharing, and Other Deferred Compensation Plans. Eighth Edition. New York: Irwin/McGraw Hill. Graham, Avy. Coordinating private pension benefits with Social Security. 
Monthly Labor Review, 1994. - Vol. 117, No. 3 (March), pp. 35-38.

Gregory, Janice. 1998. "Possible

Employer Responses to Social Security

Reform." In Prospects for Social Security Reform. Olivia Mitchell, Robert Myers, and Howard Young (eds.). Pension Research Council: University of Pennsylvania Press.

Gregory, Janice. How Might Companies Respond. Paper prepared for the 1997 Pension Research Council Symposium in Philadelphia, 1997.

Kotlmann, Geoffrey, Ray Schmitt, and Michelle Harlan. Effect of Pension Integration on Retirement Benefits. CRS Report for Congress (94-974 EP W), 1994.

McGill, Dan M., Kyle N. Brown, John J. Haley, and Sylvester J. Schieber. 1997. Fundamentals of Private Pensions. Seventh Edition. Pension Research Council.

Olsen, Kelly, Jack VanDerhei, and

Dallas L. Salisbury. 1997. “A Framework for Analyzing and Comparing Social Security Policies." In Assessing Social Security Reform Alternatives. Employee Benefit Research Institute ERF Policy Forum.

Schulz, James and Thomas Leavitt. 1983. Pension Integration; Concepts,
Issues and Proposals. Washington, DC: Employee Benefit Research Institute.

Wiatrowski, William J. New Survey Data on Pension Benefits. Monthly Labor Review, 1991. - Vol. 114, No. 8 (August), pp. 8-22 